\title{
An Exploration of Hausa Verbal Art Forms in Shaihu Umar: A Hausa Novel
}

\author{
Chaibou Elhadji Oumarou \\ Department of English, Université Abdou Moumouni de Niamey, Niamey, Niger \\ Email: chaiboue@yahoo.fr
}

Received 5 January 2015; accepted 21 January 2015; published 28 January 2015

Copyright (C) 2015 by author and Scientific Research Publishing Inc.

This work is licensed under the Creative Commons Attribution International License (CC BY). http://creativecommons.org/licenses/by/4.0/

(c) (i) Open Access

\begin{abstract}
This paper explores the Hausa verbal art forms in Shaihu Umar, a novel first published in the Hausa language and then translated into English. The paper mostly focuses on the author's use of the structures of a Hausa initiation tale as a vehicle for the narrative in the novel. In other words, the paper attempts to investigate how the author uses the structures of Hausa tales for stylistic effects. As a result, the paper tries to identify and analyze what the novel owes to the indigenous Hausa literary tradition as an illustration of the interface between orality and literacy.
\end{abstract}

\section{Keywords}

Verbal Art, Tale, Novel, Interface

\section{Introduction}

In a critical evaluation of contemporary literature in Ghana from 1911 to 1978, (Angmor, 1996: p. 39) has found two tendencies: one does not have any stylistic traces of traditional verbal art. Examples of this case are Ayi Kwei Armah's The Beautyful Ones Are Not Yet Born and Why Are We So Blest?; Joseph Abruquah's The Catechist and The Torrent; Francis Selormey's The Narrow Path; Amu Djoleto's The Strange Man and Money Galore; Bediako Asare's Rebel and Aidoo’s No Sweetness Here. The other tendency shows a clear evidence of the use of traditional verbal art forms illustrated by works such as J. E. Caseley's Ethiopia Unbound; R. E. Obeng’s Eighteenpence; A. K. Armah’s Two Thousand Seasons; Cameron Amodu’s The Gab Boy and Ama Ata Aidoo's short story, "In the Cutting of a Drink".

The common features of the works in the second new trend are their "pronounced stylistic traces of the traditional verbal art.” (Angmor, 1996: p. 41). The first two works in this category, argues Angmor, show traces of the folktale while in Two Thousand Seasons Armah uses traditional materials to create an African Saga out of the legends of the African peoples. In The Gab Boy Duodu also uses materials from the verbal art repertoire 
such as the ananse tale and drum poetry while Aidoo "uses a compressed form of the traditional story-telling style to tell a new, modern story of her own creation in her short story” (Angmor, 1996: p. 41) mentioned just above.

In conclusion, Angmor rightly observes that stylistic features such as the ones that characterize the second tendency show "how strong is the link between some manifestations of the new Ghanaian prose narrative and the traditional verbal art. This, however, is not peculiar to the new Ghanaian genre; it is evident in much of the African novel." (Angmor, 1996: p. 42; italics added) As a matter of fact, many critics of African literature agree with Angmor in this remark. Prominent among them are Jacqueline Bardolph (1987); Daniel P. Kunene (1989); Georges Ngal (1994); Josias Semujanga (1999); Pierre N’DA (2003); Romuald Fonkoua (2005); Xavier Garnier (2005); Jean Dérive (2005); Roger Tro Deho (2005); Alain Joseph Sissao (2009); etc.

Using this new trend developed by the above-mentioned critics as a stimulating inspiration, I intend to explore the Hausa verbal art forms in Shaihu Umar. This Hausa novel was originally written in the Hausa language and then translated into the English version used for this exploration. In the process of the exploration, I will mostly focus on the author's stylistic use of the structure of Hausa tales "as a vehicle for the narrative" (Angmor, 1996: p. 43) in the novel.

(Garnier, 2005: p. 23) observes that most of the emerging literatures from the south are "still invisible on the world scale" ["encore invisibles au niveau mondial"]. This observation applies to Shaihu Umar despite its popularity in the home country of its author, Alhaji Sir Abubakar Tafawa Balewa (1989), first elected Federal Prime Minister of independent Nigeria. For this reason I believe a short presentation of the novel is necessary before any exploration.

In a discussion of the background to modern Hausa prose fiction from 1920 to 1960, (Skinner, 1980: p. 168), who was a colonial administrator in Northern Nigeria at the time, reports that a Literature Bureau was created in 1930 by the Education Department of Northern Nigeria (cf. Furniss,1996). That Literature Bureau was originally named a Translation Bureau. Its main function at first was to produce Hausa textbooks for use in schools. To meet this end, a literary contest was launched throughout Northern Nigeria to discover budding novelists and publish their works.

According to (Furniss, 1988: p. 87),

Imaginative prose writing in Hausa dates specifically from the early 1930s. [A] group of five novellas was elicited from younger members of the northern elite who had gone, or were still going, through the one or two western educational institutions in Northern Nigeria at the time. The books were Shaihu Umar by A. T. Balewa, Jiki Magayi (Body Language) by John Tafida and Rupert East, Idon Matambayi (The Eye of the Inquirer) by Muhammadu Gwarzo, Ruwan Bagaja (The Water of Cure) by Abubakar Imam, and Gandoki (Mr. Inquisitive) by Bello Kagara, Abubakar Imam's elder brother. The only one of the books that has been fully translated into English is Shaihu Umar; two of the others were abridged in English to provide English school readers for Nigerian schools.

One of the reasons that led to the translation into English of Shaihu Umar has been its instant popularity in the Hausa speaking areas of Nigeria in particular. In fact, in her introduction to the American Edition, (Mack, 1989: p. 3) comments on how

The publication of Sir Abubakar Tafawa Balewa's novel Shaihu Umar in 1955 was an immediate success among Hausa speakers in Northern Nigeria, who considered the author spokesman and hero. It was reprinted in Hausa six times by 1976, and continues to be popular as a work exemplary of traditional Hausa culture and the Islamic values with which it has been infused. In 1967 it was translated [by Professor Mervin Hiskett] into the English form that appears here, and immediately went into a second printing [which is the one we are using for this analysis] the following year. The production of a film of Shaihu Umar in 1970 and a play of the same name by Umaru Ladan and Dexter Lindesay testifies to its continued popularity.

In his introduction to the English translation of which he is the author, Mervin Hiskett praises Shaihu Umar as one of the most popular of the novels and stories written by contemporary Nigerian authors. (Hiskett, 1989: p. 3) adds that "the story appears at first sight to owe less to the indigenous African literary tradition [by which he means Hausa oral traditions in particular] than, for instance, Gandoki or Magana Jari Ce, and in its wholly serious approach it is poles apart from the broad and boisterous humour of Ruwan Bagaja. But if we examine it 
more closely, native African life and customs are seen to underline the whole plot.” (Italics added)

As a matter of fact, our intention, as already mentioned earlier, is to examine Shaihu Umar more closely in order to identify the traces or elements of Hausa literary tradition and culture. Hiskett himself has called the novel a "tale" (Introduction, 1989: pp. 1, 15) while (Mack, 1989: pp. 4-6) has also referred to it as a "good tale" in her introduction to the American edition.

Both critics, however, have not really attempted to take that closer look at the novel in order to identify and analyze in full what it owes to the indigenous Hausa literary tradition. But their characterization of the novel as a tale with some indication of its relation to the storytelling tradition and its anthropological information is important enough to attract our attention and orient our research into an exploration of the Hausa traditional or verbal art forms in the novel.

As for the story of the novel, (Mack, 1989: pp. 3-4) summarizes it as follows:

The story's enduring appeal is immediately evident as the title character is introduced as an honorable man: “...there was once a certain malam, learned in the stars, in the Koran, and in the scriptures, and an upholder of the Faith. This malam was one of the men of the world to whom God has given the gift of knowledge. His name was Shaihu Umar." From such a classic beginning, the story segues into less orthodox excitements of kidnapping, slave-raids, caravans crossing the Sahara, intrigues, deaths, destruction, abandonment, and exotic adventure in West and North Africa. It is a parable of goodness triumphing over evil, and fortitude in the face of hardship. The book is an entertainment that presents the history of Northern Nigeria at the turn of the century, without ever seeming like a history lesson. The remembrance that comprises the story begins placidly enough, with Shaihu Umar in Nigeria, reminiscing about his origins: "Away back I was a native of this country, but even so, I did not grow up and pass my boyhood here. It was away in the country of the Arabs that I grew up.” As with any good tale, the adventure lies in the journey; how he got there and back is the exciting part. Before the story is finished, Umar has been kidnapped several times, captured as a slave, given to an Arab who takes him to Egypt, and finally set him free to make his way home and find his mother before she dies. Through it all he becomes a respected and revered scholar and religious man, whose fame spreads far and wide.

After this summary, let us take a closer look at the stylistic traces of Hausa tales or tatsuniyoyi (singular: tatsuniya) in the novel.

\section{Stylistic Traces of Hausa Tales in Shaihu Umar}

By stylistic traces of Hausa tales is meant here the different structural components of the Hausa tale such as the opening and closing formulas, the dialogue between the storyteller and the audience or between the author and the reader and the use of the journey motif in Shaihu Umar. First I give an example of an opening formula from a Hausa tale told by a storyteller named Hauwa Sa'idu in Zaria (north of Nigeria) in July 1967. The tale was recorded and translated from Hausa into English by (Skinner, 1980: p. 27). It reads as follows:

"My tale is about a farmer. Once there was a country in which there was a terrible famine-no food, not a bite. Well, there lived a farmer there, and he sat and thought and thought. No rain, nothing, they had no rain. And he said to himself, 'Now what can I do to get food?' So he set off and went far out into the heart of the bush, far from the town where he would get rain. There he sowed a farm, a great big one..." (Italics added).

Compare this opening formula with the one at the beginning of Shaihu Umar which reads as follows:

Near the walled city of Bauci there is a little town called Rauta. In this little town there was once a certain malam, learned in the stars, in the Koran, and in the scriptures, and an upholder of the Faith. This malam was one of the men of this world to whom God has given the gift of knowledge. His name was Shaihu Umar. So great were his learning and wisdom that news of him reached countries far distant from where he lived...(Italics added).

The two passages show some similarities, mostly in the use of the stock formula there was once in the latter example or its variant once there was in the former. The two stock formulas found in the passages are also variants of the formula: once upon a time. The two lines in italics in the passage from the tale are illustrative of the 
repetition that characterizes the oral style of tales.

In his insightful analysis of the traces of oral narrative structures in Maurice Bandaman's novel, Le fils-de-lafemme-male, (N'DA, 2003: pp. 44-45) has identified some of the most important structural elements of the oral narrative that are found not only in the novel of Bandaman but also in many other African novels. In fact, N'DA is of the opinion that

In this "tale-novel" [he is referring to Le fils-de-la-femme-male] one can find more or less all the essential elements that characterize the formal or apparent structure of the African tale and one does not need to be an expert to identify them. By elementary or apparent structure of the tale is meant all the formal components that constitute the traditional tale and which are manifest even in its analysis. These elements are varied, more or less important from one people to another, from one tale to another. They are, for example, the opening formulas or preambles with introductory songs [chamnsons-préambules] to create an atmosphere of gayety; an ambiance conducive to the beginning of tales; the stereotyped formulas such as the starting ones, the formulas preceding any speech act; the dialogue between the storyteller and his/her audience; the occasional interventions of the members of the audience; the morality formula; the closing formula; etc. (My translation) ${ }^{1}$.

An almost universal opening formula, according to (N’DA, 2003: p. 46) and (DEHO, 2005: p. 25), is "Il était une fois" which can be translated as "Once upon a time." In the Hausa tale told by Hauwa Sa'idu and in Shaihu Umar, the equivalents to this formula are "Once there was a country in which...there lived a farmer..." and "There was once a certain malam..." respectively (Italics added).

The two opening formulas in the quotes from Hauwa Sa'idu's tale and Shaihu Umar are part of what DEHO calls "formules introductives" or introductive formulas. "In the telling of the traditional tale, DEHO adds, the introductory formulas are the ones that begin the real story. These formulas locate the period of the events. What characterizes them is mostly the rupture they create on the one hand by locating the action in a remote past and on the other hand by transporting the audience [the readers in the case of the novel] into a surreal and imaginary world dominated by the marvelous and fantastic (...) where everything is possible." (Italics added) ${ }^{2}$.

At the end of the story, the narrator, Shaihu Umar, concludes in these words which constitute a closing formula:

I was not able to leave this town because my camel became sick. After six days in the place he died. Five days passed, until eventually God brought me safely to this town of yours, Rauta. Here I heard the news that Makau [his step father] had died. I had no other relative to go and see, so I settled here, teaching the Koran. So now you know the reason for my coming to your country (Italics added).

The sentences in italics are clear indication of a dialogue between the author and his audience modeled on the relationship between the storyteller and the audience (cf. DEHO, 2005). This relationship is clearly expressed right from the first chapter by the author as follows: "One day, just before evening prayer, after Shaihu Umar had been teaching his students, they were all sitting discussing the affairs of the world when one student asked him 'Master, I would like to ask you a little question...” (p. 19) After hearing the question, Umar replied: "...you have asked for a long story, and one which will cause wonder and pity in all who hear it..." (p. 19; emphasis added) The dialogue between the narrator-protagonist and a listener (one of the students who are now Umar's audience) is remindful of a traditional storytelling session. As in such a session, the storyteller's presence is felt through his frequent intervention in the first person "I" addressing the audience as "you" or "your" or "our". Other instances of such a dialogue are found mostly on the following pages:

\footnotetext{
${ }^{1}$ Dans ce “conte Romanesque” [he is referring to Le fils-de-la-femme-male], on retrouve plus ou moins tous les éléments essentiels caractéristiques de la structure formelle ou apparente du conte traditionnel africain, et il ne faut pas être grand clerc pour les identifier. Par structure apparente ou élémentaire du conte, il faut entendre l'ensemble des composantes formelles dont est fait le conte traditionnel et qui sont manifestes même sans analyse. Ces éléments sont variés, plus ou moins importants d'un peuple à l'autre, d'un conte à l'autre. Ce sont par exemple le séance d'ouverture ou le préambule avec des chansons-préambules pour créer une atmosphère de gaieté, une ambiance favorable à l'émission des contes; les formules stéréotypées telles que la formule initiale, les formules de prise de parole, le dialogue entre le conteur et son public, les interventions occasionnelles des membres de l'auditoire, la formule de moralité, la formule finale ou de clôture etc. (All the translations are mine unless otherwise indicated).

2“Dans la narration du conte traditionnel, DEHO adds, les formules introductives sont celles qui commencent le récit proprement dit. Elles situent le temps des événements. Ce qui les caractérisent, c'est surtout la rupture qu'elles opèrent d'une part en localisant l'action dans un passé lointain et d'autres part en transportant l'auditoire [les lecteurs dans le cas du roman] dans un monde surréel et imaginaire régi par le merveilleux et le fantastique (...) ou tout est possible.
} 
The reason for their delight was because, as you know, on a raid they [the courtiers] would gain many cattle and slaves as well (pp. 21-23).

When the raiders saw that they escaped, they took to the high road, for, as you know, they would not have followed the high road in the first place, lest the pagans should catch up with them (p. 23).

When she [the narrator's mother] went into the hut she had burst into tears. You know what women are like when they are happy! (p. 49).

Well, you know what men are (p. 50).

Whenever I looked at them [the Hausa slaves from northern Nigeria heading to Egypt], I would see them toiling along through the sand, bent double, their buttocks swaying side to side. O dear me, you know, it is a hard thing for a man who is used to the solid earth [of northern Nigeria] to walk through sand [in the region of Agadez in Niger] (p. 59).

Now you know what a boy is like, as the days went by I began to forget our country and my kinsfolk, and even my mother (p. 63).

The expressions "as you know," "you know," and "our" are addressed to the audience/readers who share the storyteller's/narrator's values and concerns. In addition, they express certain closeness between the storyteller/ narrator and the audience/readers. In the context of orality like this one, I agree with (Skinner, 1980: p. 8) that certain information "won't be provided by a story, but will rather be assumed by it.” This is because, as (Kunene, 1989: p. 199) has rightly noticed, “... an oral narrative depends for its success on the mutual relationship between the narrator and his audience who are held together by their common concern over the characters and events in the story. An important aspect of oral narrative is the merging of the real, objective world of the narrator and his audience, and the fictive world of the story. All participants in the performance are willing to suspend their disbeliefs and to behave as if the real world and the fictive world have merged into one. Therefore what the characters do and say and suffer and enjoy are directly shared and evaluated by the narrator and his audience."

In these circumstances, adds Kunene, the narrator can count on his audience being in "full agreement with his judgments, criticisms, approvals and disapprovals. He [does] not have to goad his audiences in that direction." Goading is not necessary because both the storyteller/narrator and his audience are physically together at the time of performance. So that the physical presence during the narration of an oral tale, (Kunene, 1989: p. 200) argues, ensures that the whole body can be used to communicate. In Kunene's opinion, this body language is of extreme relevance to the entire question of characterization "because the dramatic presentation of certain aspects of an oral narrative makes detailed character description totally unnecessary since, at these moments, the narrator is the character you can see or hear from his voice whether he is sad, happy, surprised, interested, indifferent, excited, amused, about to cry, cruel, and so on. It is an audio-visual experience in which the participants not only receive and interpret sounds, but also receive and interpret visual images.”

In the same line of thought, (DEHO, 2005: p. 32) also thinks there is no need for some information to be revealed to the audience/reader because in the context of oral performance "A permanent dialogue is created between the narrator and the narratee [or audience] in a way that the latter participates actively in the process of the elaboration and reading of the text; for he [the narratee] is supposed to share the same socio-cultural code with the narrator."(Italics added) ${ }^{3}$

Although some information is given in the quotations above from Shaihu Umar, the expressions equally draw attention to the complicity between the narrator and his audience. Parts of the information are implied in the story because the narrator assumes that the readers/audience are familiar with them.

(N’DA, 2003: pp. 48-51) says the same thing when he states:

As in a traditional storytelling session, the narrator "I" feels the need to communicate, to engage a dialogue with the reader-interlocutor whom he/she keeps constantly on the alert by calling on him, by questioning him, by considering him as a witness or by making critical comments or provocative reflections. (...) [The narratee/reader] called upon about such or such an issue feels concerned about what is happening or about that to which his/her attention is drawn. Like the audience in a storytelling session of a traditional tale, she/he [the narratee] finds himself related to the narrator through a relation of solidarity, complicity [and]

\footnotetext{
“"Il s'établit entre le narrateur et le narrataire un 'dialogue' permanent de sorte que celui-ci participe activement au processus d'élaboration et la lecture du texte, car il est censé partager le même code socioculturel que le narrateur” (Italics added).
} 
partnership (Italics added) ${ }^{4}$.

As the above quotation illustrates, Shaihu Umar is indeed full of such interpellations, invitation to witness an event and critical comments that are characteristic of the oral style. Some of these critical comments or interpellations are expressed through proverbs which are also the markers of the oral style.

According to (DEHO, 2005: p. 83), there is no one single and simple definition of proverb. In the African traditional context of oral rhetorics, says DEHO, "there is no clear cut distinction between the sapient genres such the adage, the maxim, the sentence, the apothegm, the aphorism and diction." ${ }^{5,}$ By and large, DEHO defines a proverb as "a means of expressing the thought that reflects the popular and practical experience and wisdom common to a given social group ${ }^{6}$." DEHO adds that African modern writers are no different from the traditionalists in their conception and use of proverbs. "In their works, the African writers as well do not care about these western distinctions. Thus, we call proverbs [in the context of the African novel] all the wise sayings or texts considered and used as such in the novels. In addition, it is important to point out right away that apart from the proverbs coming from the oral traditions there are those created by the novelists to meet the needs of their narrative creation ${ }^{7}$." The use of the proverbs by the narrator reflects therefore his familiarity with them as well as their importance in his social environment.

Thus, in their scheme to sow discord between the chief of the narrator's village and his step father Makau, who is considered as the chief's closest confidant, the other jealous courtiers accuse him of stealing some of the slaves they got at a raid. It is in this context of jealousy that the adversaries of Makau use the following proverb: "Let us now skin the monkey [referring to Makau] for you [the chief] right down to its tail!" (p. 24). In other words, they have now decided to reveal to the chief the true character of his confidant, Makau, to prove that the latter has not deserved the trust and esteem the chief has so far conferred upon him. Other proverbs are used as follows:

...There is never much back-biting where there is plenty, but only where poverty has its roots (p. 32). This proverb is transparent enough to need an explanation.

In a dispute over a young boy kidnapped by three slaves' raiders, one accused another of being "an ungrateful chicken." (p. 34) This expression notes the translator in note No. 2 (p. 34), is "[a] reference to the Hausa proverb: chicken, eat and wipe your beak." Wiping the beak here is synonymous with not saying thank you, which is a mark of ungratefulness. In fact, the chicken in the Hausa lore is the symbol of ungratefulness and individualism. In this context, the other slave raider is accused of being ungrateful and selfish because he refuses to compromise on how to share the only male child they were able to capture either by leaving the boy to others or by selling him to share the money among the three of them. Instead, the angry and ungrateful one beheaded the boy so that no one could have him.

The last example is a proverbial expression used by the adult narrator as follows: "I certainly learned the truth of what the lion said to the Hyena: 'Man is a thing to be feared!”” (p. 59). This proverbial expression is a lesson from Hausa animal tales, which confirms not only the influence of the oral tradition in the narrative but also the narrator's knowledge of tales from his tradition. In fact, (Hiskett, 1989: p. 3) explains the young narrator's account of how he survives an attack by a hungry hyena that eats his first kidnapper (p. 43) as being "an echo of the traditional animal fables in which this creature always figures, and [as] a further indication of the currency of these animal tales in the reference to" the above-quoted proverbial expression.

Finally there is another proverbial expression used by the rivals of Makau to plant a discord between him and the Chief. So that:

When Makau reached the Chief he prostrated himself in greeting, but the Chief did not reply. In the whole company there was not one who said as much as a single word to him. Each one just kept staring at him, and his

\footnotetext{
${ }^{4}$ Comme dans une séance de conte traditionnel, le narrateur “je” éprouve le besoin de communiquer, de dialoguer avec le lecteur-interlocuteur qu'il maintient constamment en éveil en l'interpelant, en l'interrogeant, en le prenant à témoin ou en faisant des commentaires critiques ou des réflexions provocatrices. (...) [Le narrataire/lecteur] interpellé sur tel ou tel point, se sent concerné par ce qui se passe ou par ce sur quoi son attention est attirée. Comme l'assistance dans une soirée de conte traditionnel, il se trouve lié à l'énonciateur par une relation de solidarité, de complicité, de partenariat (Italics added).

‘“[L]'on ne fait pas la distinction tranchée entre les genres sapientiaux comme l'adage, la maxime, la sentence, l’apophtegme, l’aphorisme et le dicton."

““[U]n moyen d’expression de la pensée reflétant l'expérience et la sagesse pratiques et populaires communes à un groupe social donné.”

7“Dans leurs œuvres, les auteurs africains non plus ne se soucient de ces distinctions occidentales. Aussi appellerons-nous proverbes [dans le contexte du roman africain] tous les textes sentencieux considérés et utilisés comme tels dans les romans. Par ailleurs, il faut signaler d’ores et déjà qu’à coté des proverbes issus du domaine traditionnel, il y a ceux formulés par les écrivains pour les besoins de la narration.”
} 
rivals were overjoyed, as though they had been given hump to roast! (p. 25) As the translator from the Hausa original into English has explained, "The hump of the humped cattle of Nigeria is considered a delicacy by the Hausa. Those who were given the task of roasting hump would expect to be given some for their trouble.” (p. 25; note No. 1). Of course the hump here is the narrator's step father, Makau, who is roasted in the oven of jealousy by his rivals who expect in return some favors from the chief. That favor or recompense is the chief's ban on Makau who is forced into exile after having faced a public humiliation and disgrace at the chief's place and in front of his overjoyed rivals. Let us now look at the journey motif that makes the novel fit into an initiation tale pattern.

\section{Shaihu Umar as an Initiation Tale}

In her insightful summary of the novel, (Mack, 1989: p. 4), clearly suggests that Shaihu Umar is modeled on an initiation tale through the journey of the hero-narrator:

As with any good tale, she argues, the adventure lies in the journey; how he got there [in Egypt] and back is the exciting part. Before the story is finished, Umar has been kidnapped several times, captured as a slave, given to an Arab who takes him to Egypt, and finally set him free to make his way home and find his mother before she dies. Through it all he becomes a respected and revered scholar and religious man, whose fame spreads far and wide.

The quote above points to one of the most important features of the quest hero in an initiation story: the journey motif. Many reasons can explain the necessity to embark on a journey during which the hero will have to face several obstacles that will contribute to transform him or her from an innocent boy or girl into a mature and responsible adult. In his classification of the dominant themes in the African tales, (N’DA K., 1984: p. 131) observes that the theme of initiation is indeed one of them. In addition, N'DA argues that orphan heroes are likely to undergo initiation journeys. Shaihu Umar is not an exception.

As a matter of fact, Umar was not even born when his father died. The latter left him with "the inheritance of six cows, three sheep, and his riding mare." (p. 20) Unfortunately for the orphan Umar, some years after his birth a problem arose between his step father, Makau, and the chief of the village as the result of a plot mounted by Makau's jealous rivals at the chief's palace after their return from the slave raid mentioned earlier. The immediate consequence of the plot against Makau is the confiscation of his possession, including the inheritance of the boy Umar:

Then the chief became enraged, and sent the courtiers off and gave them permission to go and ransack Makau's compound, ordering them not to leave him a single thing, even if only a sleeping mat. The courtiers went and stripped his compound to the ground, even the grass with which the roofs of the huts were thatched, all was stripped. He had some cattle in a little village near the town, and there and then someone was sent to fetch them. Now when they went to bring back these cattle of Makau, they included mine, which my father had left me as an inheritance, and also my sheep, and my mare, and her foal. After they had completely finished this pillage they gathered up the property and took it to the chief.

When it was brought Makau rose and said to the chief, "God save your Majesty, I beg you, among this property there are some things which do not belong to me, such as this mare and her foal, the sheep, and the cattle. These things belong to a certain boy, an orphan, whose mother I married. I beg you, take out this orphan's property and restore it to him" (p. 26; italics added).

After the confiscation, Makau was banned into exile with his family. Makau left the village at the indicated time without Umar and his mother who wanted to visit her parents living in a far away village. Makau gave her the permission to go but he advised her to leave Umar with someone she trusts until she comes back to wait for Makau's envoy to take her to his new village. On this they agreed. She left Umar under the care of her best friend, Amina. Shortly after her departure to see her parents, however, Umar's extraordinary adventure began. In fact, soon after while Umar was playing with other children they

“...saw a man dressed in a wide gown with a big pocket coming toward [them]. We all stopped playing and stared, watching him until he came to where we were.

When he reached us we greeted him, 'Sannu Baba.'

He said, 'Is the master of the house at home?' 
One boy from among us, a little older than the rest, said, "No, he went off into the country, but he'll be back tomorrow."

The man stood still, watching us as we played; then after a while he asked us our names. Each of us told him his name. When he heard my name I saw him stop suddenly, and fix his eyes on me. Now of all the children there, I was the smallest. After a little he called me saying, "Hello Umar, you know me, now don't you? Where is your mother, where's your father? Let's go and I'll take you to your father, eh?” (p. 40)

That is how Umar was kidnapped and began a journey that would take him to Egypt and back home. Although a very young child, Umar's kidnapping is synonymous with lack of freedom. But as the story of his journey unfolds, the reader realizes that Umar does not have to fight to get back his freedom because he has been lucky to find himself in the hands of a childless Egyptian family that adopts him as their own son. In fact, the adoptive family provides him with anything he wants such as the good Qur'anic education that makes him become a famous religious scholar worldwide. Meanwhile, his mother has been suffering since she learned about his kidnapping and decided to follow his traces in order to find him. She finally met him but she was in a very terrible health condition because unlike her son, she suffered a lot during her journey. She soon died after seeing her son who decided to return back to his native country. His adoptive family did not oppose his return because it was part of the promise the adoptive father made to Umar before buying him from Gumuzu, his former owner in Kano.

As said earlier, our concern is in the journey motif and what it stands for in terms of experience for the protagonist. In fact, even though Umar may be considered an exceptionally lucky slave, he did have to face some obstacles during his journey. Beverly Mack has beautifully summarized that experience which has shaped his character in the quote used earlier. Like any initiate of African tales, Umar returns home a very different person. He is mature and wiser in the way he epitomizes the Hausa concept of mutumin kirki, the good man. The rich and wide experience he acquired through the journey makes him qualify as a quest hero of the initiation tales.

In the light of the above exploration of the Hausa verbal art forms in Shaihu Umar, it is appropriate to conclude that its author has made a conscious use of the formal structures of the Hausa tales. In his Ph.D. dissertation entitled "The Oral Tradition and the Beginning of Hausa Fiction," (Westley,1986: p. 74) rightly states that in the Hausa novels Gandoki, Idon Matambayi and Shaihu Umar "It is almost as if each author were supplying an audience setting for what is, by the nature of the act of reading itself, a solitary experience." (Emphasis added) Although writing before the independence of Nigeria, Tafawa Balewa's use of the stylistic features of the Hausa oral traditions is illustrative of the new literary trend that characterizes the African literature mainly after independence and which is still characteristic of the African novel in search of an African identity and originality.

\section{References}

Angmor, C. (1996). Contemporary Literature in Ghana 1911-1978: A Critical Evaluation. Accra New Town: Woeli Publishing Services.

Balewa, A. S. A. T. (1989). Shaihu Umar. New York: Markus Wiener Publishing, Inc.

Dérive, J. (2005). L’approche Critique des Littératures en Langues Africaines. Notre Librairie, 28-33.

Fonkoua, R. (2005). Naissance d'une Critique Littéraire en Afrique Noire. Notre Librairie, 8-15.

Furniss, G. (1988). Hausa Creative Writing in the 1930s: An Exploration in Postcolonial Theory. Research in African Literature, 29, 87-102.

Garnier, X. (2005). Entre définitions et étiquettes: Les problèmes de catégorisation des littératures “du sud”. Notre Librairie, 22-27.

Hiskett, M. (1989). Introduction. In A. S. A. T. Balewa (Ed.), Shaihu Umar (pp. 3-15). New York: Markus Wiener Publishing, Inc.

Kunene, D. P. (1989). Thomas Mofolo and the Emergence of Written Sesotho Prose. Johannesburg: Raven Press.

Mack, B. (1989). Introduction. In T. Balewa (Ed.), Shaihu Umar (pp. 3-13). New York: Markus Wiener Publishing, Inc.

N'DA K., P. (1984). Le conte africain et l'éducation. Paris: L'Harmattan.

N’DA, P. (2003). L'écriture Romanesque de Maurice Bandaman: Ou la quête d'une esthétique africaine moderne. Paris: L'Harmattan.

Ngal, G. (1994). Création et rupture en littérature africaine. Paris: L’Harmattan.

Semujanga, J. (1999). Dynamique des Genres dans le roman africain: Eléments de poétique transculturelle. Paris: 
L'Harmattan.

Sissao, A. J. (2009). Les rapports oralité écriture à travers Allah n’est pas obligé d’Ahmadou Kourouma. In A. J. Sissao (Ed.), Oralité et écriture: La littérature écrite face aux défis de la parole traditionnelle (pp. 161-172). Ouagadougou: CNRST/ Agence Universitaire de la Francophonie.

Skinner, N. (1980). An Anthology of Hausa Literature in Translation. Zaria: Northern Nigeria Publishing Co. Ltd.

Deho, T. R. (2005). Création romanesque négro-africaine et ressources de la littérature orale. Paris: L’Harmattan.

Westley, D. (1986). The Oral Tradition and the Beginning of Hausa Fiction. Ph.D. Dissertation, Madison, WI: University of Wisconsin. 
Scientific Research Publishing (SCIRP) is one of the largest Open Access journal publishers. It is currently publishing more than 200 open access, online, peer-reviewed journals covering a wide range of academic disciplines. SCIRP serves the worldwide academic communities and contributes to the progress and application of science with its publication.

Other selected journals from SCIRP are listed as below. Submit your manuscript to us via either submit@scirp.org or Online Submission Portal.
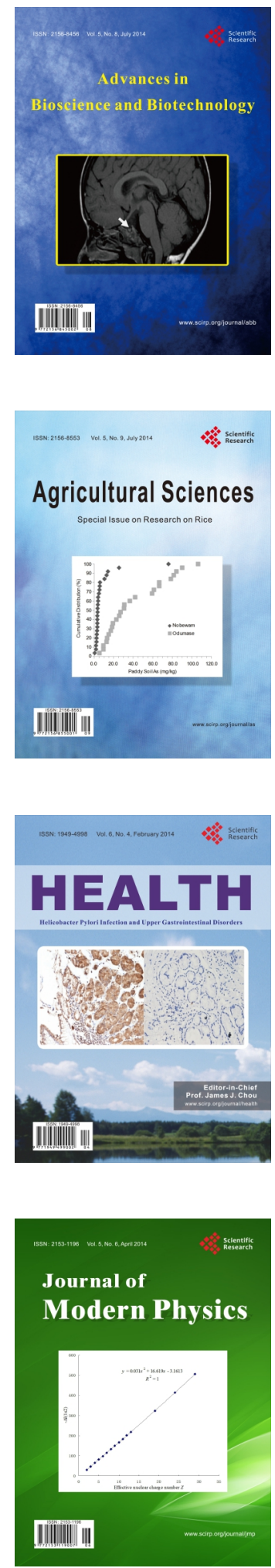
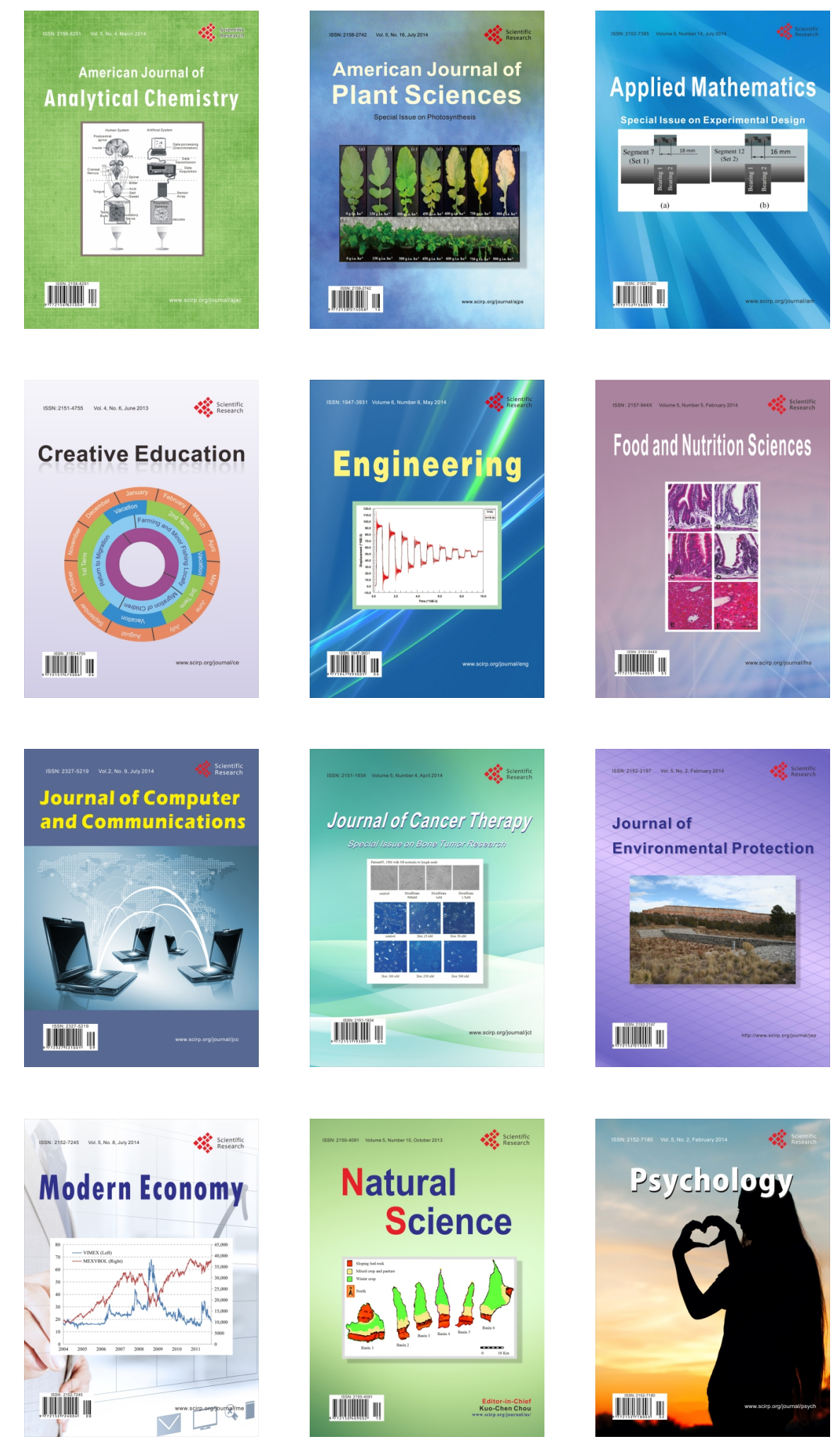